Original Article

\title{
Evaluation of Microbial Contamination of Dried Black Curd (Gharahghorut) Produced in Iran
}

\begin{abstract}
Mojtaba Chizari
(MSc) Department of Microbiology and Microbial Biotechnology, Faculty of Life Sciences and Biotechnology, Shahid Beheshti University, Tehran, Iran

Seyed Masoud Hosseini

(PhD) Department of Microbiology and Microbial Biotechnology, Faculty of Life Sciences and Biotechnology, Shahid Beheshti University, Tehran, Iran

Ali Mohammadi

(PhD) Department of Microbiology, Faculty of Biological Sciences, Alzahra University, Tehran, Iran

Javad Fakhari

(MSc) Department of Microbiology and Microbial Biotechnology, Faculty of Life Sciences and Biotechnology, Shahid Beheshti University, Tehran, Iran

Mojtaba Mashhadi MohammadzadehVazifeh

(MSc) Department of Microbiology and Microbial Biotechnology, Faculty of Life Sciences and Biotechnology, Shahid Beheshti University, Tehran, Iran

Corresponding author: Seyed Masoud Hosseini

Email: Ma Hosseini@sbu.ac.ir

Tel: +9829905913
\end{abstract}

Address: Department of Microbiology and Microbial Biotechnology, Faculty of Life Sciences and Biotechnology, Shahid Beheshti University, Tehran, Iran

Received: 2020/04/24

Revised: 2020/06/14

Accepted: 2020/07/26

\section{c) (i) (9)}

This work is licensed under a Creative Commons Attribution 4.0 License.

\author{
ABSTRACT \\ Background and objectives: Dried Black Curd (DBC), also \\ known as Gharahghorut (Persian), is a dairy product produced \\ from curd of yogurt or doogh. The aim of this study was to \\ evaluate microbial contamination of industrially and traditionally \\ produced DBC in Iran.
}

Methods: Four DBC brands holding certification of the Institute of Standards and Industrial Research of Iran (ISIRI), Iran Ministry of Health and Medical Education (IMHME) and ISO were purchased from a market in Tehran, Iran. Microbial monitoring for presence of coliform, Escherichia coli, coagulasepositive Staphylococcus aureus, mold and yeast was performed using different basic, enriched, selective and differential media including peptone water agar, MacCankey agar, blood agar and brain heart infusion agar, etc. according to the ISIRI standards (No.13299).

Results: None of the tested samples had microbial contamination. However, in one traditional DBC sample, the population of mold and yeast was higher than the acceptable level defined by the ISIRI standard.

Conclusion: We found no contamination with coagulasepositive S. aureus, E. coli and coliforms in four brands of traditionally and industrially produced DBC in Iran. This indicates that the hygienic practices designated by the IMHME are well-implemented in the industrial sector. However, the mold and yeast contamination in traditionally produced DBC should be prevented by applying hygienic practices during the process of manufacturing and distribution.

Keyword: Dried black curd (DBC), Gharahghorut, Microbial Contamination 


\section{INTRODUCTION}

Dried black curd (DBC), also known as gharehghorut, gharaghorut, black kashk or qara, is a traditional milk product with black, brown, white or yellow color and a very sour taste. This stiff, sour and chewable dairy product is basically produced by boiling the yogurt whey derived from mixture of kashk, buttermilk and whey. It is used alone or along with other raw materials for producing fruit leather. It is rich in lactic acid and contains some minerals such as calcium and vitamins, especially vitamin $B_{2}$ (1). Based on the preparation method provided in the Moeen Encyclopedia, doogh is boiled and dried in a thick bag. Then, tuff or the remaining matter is shaped as bullets and further dried under sunlight. Finally, the sour water extracted from the bag is exposed to sunlight or boiled dry in order to obtain gharaghorut.

The hardness, softness, taste and color of DBC depends on the amount and method of heating, the level of fat, evaporated water, acidity and sour. The composition of DBC is summarized in table 1. A healthy and standard DBC should be free from mold and warehouse pests, unpleasant and unnatural taste and smell, external materials such as pebble, hair and burnt particles, color, additives and preservatives (1).

Gharaghorut is mainly produced traditionally at homes and less frequently in small factories. Accordingly, it is essential for producers to receive an official hygiene code. Food spoilage can easily occur in the production process, while physical, chemical and biological contamination can have both health and economic consequences. Spoilage also decreases the shelf life of the product and may lead to food poisoning (2). Therefore, microbial control of food products is a critical step to increase shelf life while maintaining quality (3). The $\mathrm{pH}$ of DBC is low due to the high concentration of lactic acid, which limits the growth of microorganisms.
However, ignoring food hygiene regulations can result in increased risk of DBC contamination with foodborne pathogens, such as Escherichia coli, Staphylococcus aureus and molds. The present study aimed to assess microbial contamination of traditionally and industrially produced DBC in Iran.

\section{MATERIALS AND METHODS}

All reagents and microbial culture media used in the experiments were based on the recommendations of ISIRIs (No. 2461-1, 2946, 6806-3 and 10899-2) (4-7). Sampling was performed based on the standard sampling protocol for agricultural products that are consumed orally (ISIRI No. 2836) (8). Characteristics of DBC samples from manufacturers in Tehran (Iran) as well as the type of certifications issued by different authorities including the Iran Ministry of Health and Medical Education (IMHME), ISIRI, HACCP, ISO 9001 and ISO 22000 are summarized in table 2. Different DBC brands were purchased from a market in Tehran and were kept at $18-25^{\circ} \mathrm{C}$ (Figure 1).

The $\mathrm{pH}$ of DBC samples was determined and microbial features were assessed using general, enriched, selective and differential media. In addition, presence of E. coli, coagulase-positive $S$. aureus, coliforms, mold and yeast was evaluated based on the protocols provided by the ISIRI (No. 13299) (9). The chemical composition of two DBC samples was analyzed. All measurements were carried out three times.

Coliforms were isolated by using the most probable number (MPN) and colony counting methods using enterobacteria enrichment (EE) broth (Cat No. 651702, Quelab Inc., Canada), violet red bile glucose agar (No. 651702, Quelab Inc., Canada) and nutrient agar (Cat No. 105450, Merck, Germany) and incubation for 24 hours at $37{ }^{\circ} \mathrm{C}$. Glucose oxidase fermentation test was conducted using glucose agar (Cat No. 651135, Quelab Inc., Canada) for further confirmation (ISIRI No. $11165 \& 1,2-2461)(10-12)$.

Table 1. Sensory and physical characteristics of DBC based on the Institute of Standards and Industrial Research of Iran (ISIRI, No. 13299)

\begin{tabular}{|c|c|}
\hline Indicator & Description \\
\hline Color & The product should be uniform with a cream to dark blackish-brown color. \\
\hline Taste and smell & DBC should possess sour taste without any unpleasant and unnatural smell. \\
\hline $\begin{array}{c}\text { Consistency and } \\
\text { texture }\end{array}$ & The product should have a uniform texture in form of concentrated liquid to solid phase. \\
\hline
\end{tabular}


Table 2. Characteristics of the purchased DBC brands

\begin{tabular}{|c|c|c|c|c|}
\hline Sample code & $\mathbf{A}$ & B & $\mathbf{C}$ & D \\
\hline Number of sample & Three & Three & Three & Three \\
\hline Production method & Industrial & Industrial & Traditional & Traditional \\
\hline Color & White & Black & White & Black \\
\hline Hygiene code (IMHME) & $\checkmark$ & $\checkmark$ & $\mathrm{x}$ & $\mathrm{x}$ \\
\hline ISO 22000:2005 & $\mathrm{x}$ & $\mathrm{x}$ & $\mathrm{x}$ & $\mathrm{x}$ \\
\hline НАССР & $\mathrm{x}$ & $\mathrm{x}$ & $\mathrm{x}$ & $\mathrm{x}$ \\
\hline Standard logo (ISIRI) & $\checkmark$ & $\checkmark$ & $\mathrm{x}$ & $\mathrm{x}$ \\
\hline Production date & $\checkmark$ & $\checkmark$ & $\mathrm{x}$ & $\mathrm{x}$ \\
\hline
\end{tabular}

Note: the characteristics of samples A and B were written on their packages.

Figure 1. Color and appearance of the purchased DBC brands

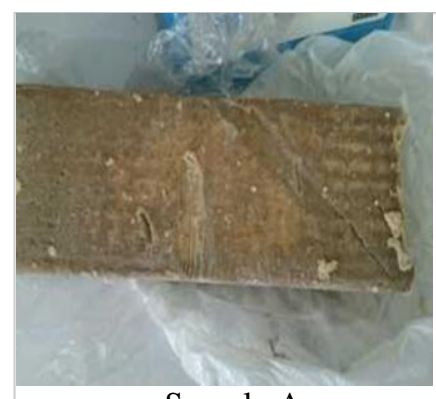

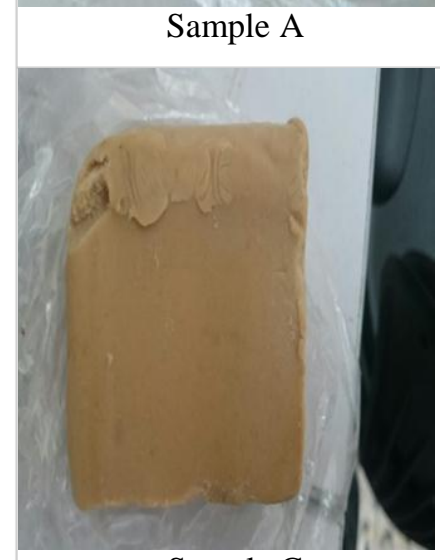

Sample C

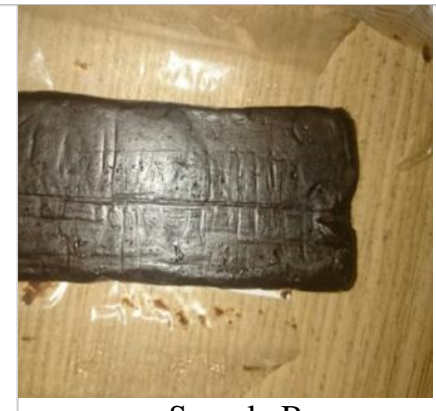

Sample B

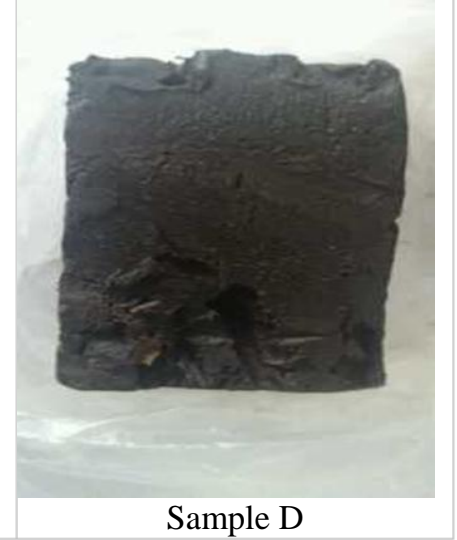

The MPN technique and lauryl sulfate broth (No. 652406, Quelab Inc., Canada), EC broth (Cat No. 110285, Merck, Germany) and peptone water indole free (Cat No. 652106, Quelab Inc., Canada) were applied to isolate $E$. coli, which was confirmed by indole (ISIRI No. 2946) (6). Coagulase-positive S. aureus were isolated using the MPN technique (5) and Giolitti-Cantoni broth (Cat No. 836930, Quelab Inc., Canada), Baird Parker agar (Cat No. 105406, Merck, Germany) and brain heart infusion (BHI) broth (Cat No. 180239, Quelab Inc., Canada).
In addition, rabbit plasma (Cat No. 113306, Merck, Germany) was used for confirmatory test (ISIRI No. 3-6806) (13). The spread plate technique was used to isolate and count molds and yeasts. In this regard, samples were incubated in dichloran glycerol (DG18) agar (Cat No. 620238, Liofilchem, Italy) for 5-7 days at $25^{\circ} \mathrm{C}$ (ISIRI No. 2-10899) (7).

After evaluating microbial contamination, the obtained values were compared to standard levels (14).

The protein content of samples was determined via the Kjeldahl method based on 
the ISIRI standard (No. 1-9188) with standard acceptance level (SAL) of 8-12 (g/percent)

(15). The fat content of samples was measured using the Soxhlet method based on the ISIRI standard (No. 760) with SAL of $\leq 1$ (g/percent) (16). The ash content of samples was determined through ash analysis in a furnance $\left(550{ }^{\circ} \mathrm{C}\right.$ ) based on the ISIRI standard (No. $1755)$ with $\mathrm{SAL}$ of $\leq 9$ (g/percent) (17). Moisture level was determined based on the ISIRI standard (No. 1753) with SAL of 15-30 (g/percent) (15).

The calcium content of DBC was determined using a Young Lin AAS 8020 atomic absorption spectrometer (South Korea) with 99.7\% burnt acetylene based on the ISIRI standard (No. 9266). Moreover, the Unico UV / Vis 2100 spectrophotometer (USA) was used to measure phosphorus level based on the ISIRI standard (No. 1808 (18). The method is based on digestion of DBC samples in sulphuric acid and hydrogen peroxide, then adding molybdate solution and ascorbic acid, and finally measuring phosphate in the solution at $820 \mathrm{~nm}$ (19).

\section{RESULTS}

Table 3 presents the results of culturing DBC samples in culture media with different conditions. No microbial growth was observed in culture of peptone water, plate count agar, MacConkey agar, blood agar, MRS agar, M17 agar, nutrient agar, glucose agar, YM agar, two phases, BHI agar, EMB and peptone water agar under different $\mathrm{pH}$ and aerobic/anaerobic conditions.

Table 3. Results of culturing DBC samples in general, selective and differential media

\begin{tabular}{|c|c|c|c|c|c|}
\hline \multirow[t]{2}{*}{ Culture medium } & \multirow[t]{2}{*}{ Culture condition } & \multicolumn{4}{|c|}{ Results of culturing DBC samples } \\
\hline & & Sample A & Sample B & Sample C & Sample D \\
\hline Peptone water & $\begin{array}{c}\text { Natural pH } \\
\text { pH } 3 \\
\text { Anaerobic with natural pH } \\
\text { Anaerobic with acidic pH }\end{array}$ & $\begin{array}{l}\text { ND } \\
\text { ND } \\
\text { ND } \\
\text { ND }\end{array}$ & $\begin{array}{l}\text { ND } \\
\text { ND } \\
\text { ND } \\
\text { ND }\end{array}$ & $\begin{array}{l}\text { ND } \\
\text { ND } \\
\text { ND } \\
\text { ND }\end{array}$ & $\begin{array}{l}\text { ND } \\
\text { ND } \\
\text { ND } \\
\text { ND }\end{array}$ \\
\hline Plate count agar & $\begin{array}{c}\text { Natural } \mathrm{pH} \\
\mathrm{pH} 3 \\
\text { Anaerobic with natural pH } \\
\text { Anaerobic with acidic pH }\end{array}$ & $\begin{array}{l}\text { ND } \\
\text { ND } \\
\text { ND } \\
\text { ND }\end{array}$ & $\begin{array}{l}\text { ND } \\
\text { ND } \\
\text { ND } \\
\text { ND }\end{array}$ & $\begin{array}{l}\text { ND } \\
\text { ND } \\
\text { ND } \\
\text { ND }\end{array}$ & $\begin{array}{l}\text { ND } \\
\text { ND } \\
\text { ND } \\
\text { ND }\end{array}$ \\
\hline MacConkey agar & $\begin{array}{c}\text { Natural } \mathrm{pH} \\
\mathrm{pH} 3 \\
\text { Anaerobic with natural pH } \\
\text { Anaerobic with acidic pH }\end{array}$ & $\begin{array}{l}\text { ND } \\
\text { ND } \\
\text { ND } \\
\text { ND }\end{array}$ & $\begin{array}{l}\text { ND } \\
\text { ND } \\
\text { ND } \\
\text { ND }\end{array}$ & $\begin{array}{l}\text { ND } \\
\text { ND } \\
\text { ND } \\
\text { ND }\end{array}$ & $\begin{array}{l}\text { ND } \\
\text { ND } \\
\text { ND } \\
\text { ND }\end{array}$ \\
\hline Blood agar & $\begin{array}{c}\text { Natural pH } \\
\text { pH } 3 \\
\text { Anaerobic with natural pH } \\
\text { Anaerobic with acidic pH }\end{array}$ & $\begin{array}{l}\text { ND } \\
\text { ND } \\
\text { ND } \\
\text { ND }\end{array}$ & $\begin{array}{l}\text { ND } \\
\text { ND } \\
\text { ND } \\
\text { ND }\end{array}$ & $\begin{array}{l}\text { ND } \\
\text { ND } \\
\text { ND } \\
\text { ND }\end{array}$ & $\begin{array}{l}\text { ND } \\
\text { ND } \\
\text { ND } \\
\text { ND }\end{array}$ \\
\hline MRS agar & $\begin{array}{c}\text { Natural } \mathrm{pH} \\
\mathrm{pH} 3 \\
\text { Anaerobic with natural pH } \\
\text { Anaerobic with acidic pH }\end{array}$ & $\begin{array}{l}\text { ND } \\
\text { ND } \\
\text { ND } \\
\text { ND }\end{array}$ & $\begin{array}{l}\text { ND } \\
\text { ND } \\
\text { ND } \\
\text { ND }\end{array}$ & $\begin{array}{l}\text { ND } \\
\text { ND } \\
\text { ND } \\
\text { ND }\end{array}$ & $\begin{array}{l}\text { ND } \\
\text { ND } \\
\text { ND } \\
\text { ND }\end{array}$ \\
\hline M17 agar & $\begin{array}{c}\text { Natural pH } \\
\text { pH 3 } \\
\text { Anaerobic with natural pH } \\
\text { Anaerobic with acidic pH }\end{array}$ & $\begin{array}{l}\text { ND } \\
\text { ND } \\
\text { ND } \\
\text { ND }\end{array}$ & $\begin{array}{l}\text { ND } \\
\text { ND } \\
\text { ND } \\
\text { ND }\end{array}$ & $\begin{array}{l}\text { ND } \\
\text { ND } \\
\text { ND } \\
\text { ND }\end{array}$ & $\begin{array}{l}\text { ND } \\
\text { ND } \\
\text { ND } \\
\text { ND }\end{array}$ \\
\hline Nutrient agar & $\begin{array}{c}\text { Natural pH } \\
\text { pH } 3 \\
\text { Anaerobic with natural pH } \\
\text { Anaerobic with acidic pH }\end{array}$ & $\begin{array}{l}\text { ND } \\
\text { ND } \\
\text { ND } \\
\text { ND }\end{array}$ & $\begin{array}{l}\text { ND } \\
\text { ND } \\
\text { ND } \\
\text { ND }\end{array}$ & $\begin{array}{l}\text { ND } \\
\text { ND } \\
\text { ND } \\
\text { ND }\end{array}$ & $\begin{array}{l}\text { ND } \\
\text { ND } \\
\text { ND } \\
\text { ND }\end{array}$ \\
\hline Glucose agar & $\begin{array}{c}\text { Natural pH } \\
\text { pH } 3 \\
\text { Anaerobic with natural pH } \\
\text { Anaerobic with acidic pH }\end{array}$ & $\begin{array}{l}\text { ND } \\
\text { ND } \\
\text { ND } \\
\text { ND }\end{array}$ & $\begin{array}{l}\text { ND } \\
\text { ND } \\
\text { ND } \\
\text { ND }\end{array}$ & $\begin{array}{l}\text { ND } \\
\text { ND } \\
\text { ND } \\
\text { ND }\end{array}$ & $\begin{array}{l}\text { ND } \\
\text { ND } \\
\text { ND } \\
\text { ND }\end{array}$ \\
\hline YM agar & $\begin{array}{c}\text { Natural } \mathrm{pH} \\
\mathrm{pH} 3 \\
\text { Anaerobic with natural pH } \\
\text { Anaerobic with acidic } \mathrm{pH}\end{array}$ & $\begin{array}{l}\text { ND } \\
\text { ND } \\
\text { ND } \\
\text { ND }\end{array}$ & $\begin{array}{l}\text { ND } \\
\text { ND } \\
\text { ND } \\
\text { ND }\end{array}$ & $\begin{array}{l}\text { ND } \\
\text { ND } \\
\text { ND } \\
\text { ND }\end{array}$ & $\begin{array}{l}\text { ND } \\
\text { ND } \\
\text { ND } \\
\text { ND }\end{array}$ \\
\hline Two phases & $\begin{array}{c}\text { Natural } \mathrm{pH} \\
\mathrm{pH}: 3 \\
\text { Anaerobic with natural } \mathrm{pH} \\
\text { Anaerobic with acidic } \mathrm{pH}\end{array}$ & $\begin{array}{l}\text { ND } \\
\text { ND } \\
\text { ND } \\
\text { ND }\end{array}$ & $\begin{array}{l}\text { ND } \\
\text { ND } \\
\text { ND } \\
\text { ND }\end{array}$ & $\begin{array}{l}\text { ND } \\
\text { ND } \\
\text { ND } \\
\text { ND }\end{array}$ & $\begin{array}{l}\text { ND } \\
\text { ND } \\
\text { ND } \\
\text { ND }\end{array}$ \\
\hline BHI agar & $\begin{array}{c}\text { Natural } \mathrm{pH} \\
\mathrm{pH}: 3 \\
\text { Anaerobic with natural } \mathrm{pH} \\
\text { Anaerobic with acidic } \mathrm{pH}\end{array}$ & $\begin{array}{l}\text { ND } \\
\text { ND } \\
\text { ND } \\
\text { ND }\end{array}$ & $\begin{array}{l}\text { ND } \\
\text { ND } \\
\text { ND } \\
\text { ND }\end{array}$ & $\begin{array}{l}\text { ND } \\
\text { ND } \\
\text { ND } \\
\text { ND }\end{array}$ & $\begin{array}{l}\text { ND } \\
\text { ND } \\
\text { ND } \\
\text { ND }\end{array}$ \\
\hline EMB & $\begin{array}{c}\text { Natural } \mathrm{pH} \\
\mathrm{pH}: 3 \\
\text { Anaerobic with natural } \mathrm{pH} \\
\text { Anaerobic with acidic } \mathrm{pH}\end{array}$ & $\begin{array}{l}\text { ND } \\
\text { ND } \\
\text { ND } \\
\text { ND }\end{array}$ & $\begin{array}{l}\text { ND } \\
\text { ND } \\
\text { ND } \\
\text { ND }\end{array}$ & $\begin{array}{l}\text { ND } \\
\text { ND } \\
\text { ND } \\
\text { ND }\end{array}$ & $\begin{array}{l}\text { ND } \\
\text { ND } \\
\text { ND } \\
\text { ND }\end{array}$ \\
\hline Peptone water agar & $\begin{array}{c}\text { Natural } \mathrm{pH} \\
\mathrm{pH}: 3 \\
\text { Anaerobic with natural } \mathrm{pH} \\
\text { Anaerobic with acidic } \mathrm{pH}\end{array}$ & $\begin{array}{l}\text { ND } \\
\text { ND } \\
\text { ND } \\
\text { ND }\end{array}$ & $\begin{array}{l}\text { ND } \\
\text { ND } \\
\text { ND } \\
\text { ND }\end{array}$ & $\begin{array}{l}\text { ND } \\
\text { ND } \\
\text { ND } \\
\text { ND }\end{array}$ & $\begin{array}{l}\text { ND } \\
\text { ND } \\
\text { ND } \\
\text { ND }\end{array}$ \\
\hline
\end{tabular}


In samples A and B that were holders of the health code and ISIRI logo and other samples, no isolate was found in the tests related to coliform, E. coli, coagulase-positive $S$. aureus, mold and yeast. However, the number of molds and yeasts in samples $\mathrm{C}$ and $\mathrm{D}$ was $1 \times 10^{2}$ and $3 \times 10^{3}$, respectively.

Table 5 shows the composition of an industrial sample (A, white DBC) and a traditional sample (C, white DBC).

\section{DISCUSSION}

As a traditional dairy product, $\mathrm{DBC}$ has been produced and consumed in various parts of Iran. Our study is the first to evaluate microbial contamination of both industrially and traditionally produced DBC in Iran. This dairy product is rich in protein and contains high amounts of calcium, minerals and vitamins. Thus, paying attention to this valuable product and improving its microbial quality can be beneficial for the public health, nutrition and development of the export sector. The results showed no microbial contamination in the tested samples of DBC. The low microbial load can be caused by inprocess high-temperature and repeated heating, very low $\mathrm{pH}$ and low percentage of active water and salt. Tajizadegan et al. conducted a study on contamination of traditional kashk and DBC with Salmonella, coliform, E. coli and S. aureus.
They found contamination with E. coli and coliform in $7 \%$ and $27 \%$ of the samples, respectively. However, there was no contamination with Salmonella and S. aureus (20). Unlike our study, the mentioned study assessed traditional DBC based on the ISIRI standard for kashk not DBC.

The results indicated that the population of mold and yeast in traditional DBC samples exceeded the standard level. However, implementing good hygiene practices in the traditional production process may considerably reduce the extent of contamination.

The shelf life of DBC is long due to its low $\mathrm{pH}$. Industrially produced DBCs had a twoyear expiry date. It should be noted that the packages should be resistant to acid and prevent the transfer of packaging materials to the product, spoilage, contamination, drying or exchange of moisture and smell (1). Furthermore, DBC should be kept in a cool, dry place and away from direct sunlight. The lack of microbial contamination in DBC samples could also be due to the probable presence of growth inhibitors such as bacteriophage and added materials containing antibiotics, residues of sterilizing agent and detergents, free fatty acids or substances present in unprocessed food such as niacin as well as natural antimicrobial proteins present in the DBC (21).

Table 4. Indicator microbes' counts with standard acceptance level (number/g)

TEST NUMBER OF ISOLATED MICROBES

(MPN/G)

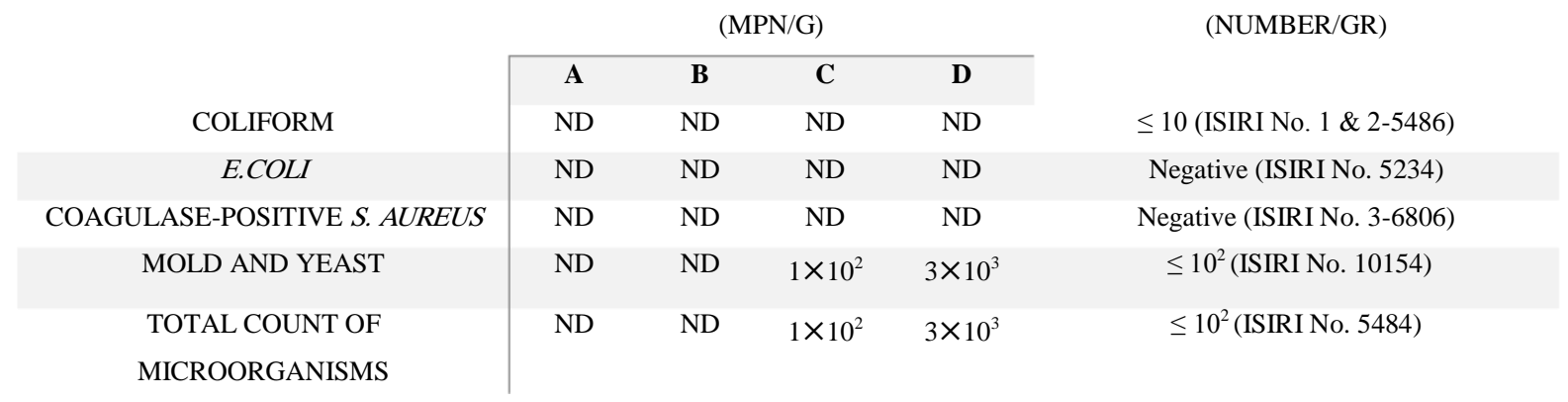

ND: not detected
Table 5. Quantitative composition of samples A and C

$\begin{array}{ccc}\text { Sample } & \text { A } & \text { C } \\ \text { (g/percent }) & \text { (g/percent) } \\ \text { Protein } & 8.40 & 5.16 \\ \text { Fat } & 0.40 & 0.30 \\ \text { Ash } & 11.90 & 8.10 \\ \text { Moisture } & 18.64 & 17.80 \\ \text { Dry matter } & 81.36 & 82.20 \\ \text { Calcium } & 1.70 & 1.95 \\ \text { Phosphorus } & 0.88 & 1.13\end{array}$


The protein content of sample A (8.40 $\mathrm{g} /$ percentage) was at the allowed level, but the protein content of sample C $\quad(5.16$ $\mathrm{g} /$ percentage) was lower than the standard value defined by the ISIRI for DBC (8-12 $\mathrm{g} /$ percentage). The difference in the protein content of the products could be related to the raw materials used in the traditional and industrial preparation of DBC. The fat content of both sample A (0.40 g/percentage $)$ and sample C $(0.30 \mathrm{~g} /$ percentage $)$ was at the allowed level compared to the standard value defined for DBC (max. $1 \mathrm{~g} /$ percent). The moisture content of sample $\mathrm{A}$ and $\mathrm{C}$ was determined as 18.64 and $17.80 \mathrm{~g} /$ percentage, respectively, both of which were at the allowed level compared to the defined value by the ISIRI for DBC (max. 15-30 g/percent). Therefore, DBC could be considered a healthy dairy product with a long shelf life due to its low fat and moisture content compared to other dairy products. Sample A and C included 11.90 and $8.10 \mathrm{~g} /$ percent of ash, respectively. The ash content of sample A was higher than the allowed value defined by the ISIRI standard (max. 9 g/percentage). Ash represents the mineral content of DBC and its different values may be related to the level of minerals consumed by the livestock whose milk was used for DBC preparation. The phosphorus content of samples $\mathrm{A}$ and $\mathrm{C}$ was determined as 0.88 and $1.13 \mathrm{~g} /$ percent, respectively. Moreover, the calcium content of samples $\mathrm{A}$ and $\mathrm{C}$ was determined as 1.70 and $1.90 \mathrm{~g} /$ percent, respectively. Calcium is considered as the most abundant mineral in the body, which is required for strengthening of bones and teeth, muscle contraction, secretion of specific hormones and proper functioning of some enzymes as well as the nervous system. There are $125 \mathrm{mg}$ of calcium in $100 \mathrm{~g}$ of low-fat milk and yogurt and the value is lower in high-fat milks (4). Considering the favorable calcium content of DBC compared to that of milk and its products, DBC can be considered as a nutritious condiment and a suitable source of calcium and other minerals for individuals who do not consume milk or yogurt.

\section{CONCLUSION}

We found no contamination with coagulase-positive $S$. aureus, E. coli and coliforms in four brands of traditionally and industrially produced DBC in Iran.
This indicates that the hygienic practices designated by the IMHME are wellimplemented in the industrial sector. However, the mold and yeast contamination in traditionally produced DBC should be prevented by applying hygienic practices during the process of manufacturing and distribution.

\section{ACKNOWLEDGEMENTS}

The authors would like to thank Research and Development Department of Shahid Beheshti University for the financial support.

\section{CONFLICT OF INTEREST}

The authors declare that there is no conflict of interest.

\section{REFERENCES}

1. ISIRI (Institute of Standards and Industrial Research of Iran). Gharahghorut-Specifications and test methods. 2011;No:13299(ICS:67.100.99).

2. Smith JP, Daifas DP, El-Khoury W, Koukoutsis J, ElKhoury A. Shelf life and safety concerns of bakery products-a review. Crit Rev Food Sci Nutr. 2004; 44(1): 19-55. doi: 10.1080/10408690490263774.

3. ISIRI (Institute of Standards and Industrial Research of Iran). Microbiological of pastry and confectionary products-specifications and test method. 2019; No:2395:5-11.

4. ISIRI (Institute of Standards and Industrial Research of Iran). Microbiology of food and animal feeding stuffs-Horizontal methods for the detection and enumeration of Enterobacteriaceae - Part 1: Detection and enumeration by MPN technique with perenrichment. 2007;No: 2461:1.

5. ISIRI (Institute of Standards and Industrial Research of Iran). Microbiology of food and animal feeding stuffs-Horizontal method for the enumeration of coagulase- positive Staphylococci (Staphylococcus aureus and other species) - Part 3: Detection and MPN technique for low numbers. 2006;No: 6806-3.

6. ISIRI (Institute of Standards and Industrial Research of Iran). Microbiology of food and animal feeding stuffs -Detection and enumeration of presumptive Escherichia coli -Most probable number technique. 2005;No: 2946(ICS:30.100.07).

7. ISIRI (Institute of Standards and Industrial Research of Iran). Microbiology of food and animal feeding stuffs - Horizontal method for the enumeration of yeasts and molds - Part 2: Colony count technique in products with water activity less than or equal to 0.9. 2008; No: 10899-.

8. ISIRI (Institute of Standards and Industrial Research of Iran). Packaged agricultural products used in food industry-Sampling. 2018; No: 2836(ICS: 67.040).

9. Mohammadi A, Hashemi M, Hosseini SM. Comparison of antifungal activities of various essential oils on the Phytophthora drechsleri, the causal agent of fruit decay. Iran J Microbiol. 2015; 7(1): 31-7.

10. ISIRI (Institute of Standards and Industrial Research of Iran). Microbiology of the food chain-Horizontal method for the detectionand enumeration of Enterobacteriaceae. Part 2: Colony-count technique. 2018; No: 2461-2(ICS: 07.100.01).

11. ISIRI (Institute of Standards and Industrial Research 
of Iran). Microbiology of food and animal feeding stuffs - Horizontal method for the detection and enumeration of coliforms - Most probable number technique. 2010; No: 11166(ICS: 07.100.30).

12. ISIRI (Institute of Standards and Industrial Research of Iran). Microbiology of the food chain-Horizontal method for the detectionand enumeration of EnterobacteriaceaePart 1: Detection of Enterobacteriaceae. 2018;No: 2461-1(ICS: 07.100.30).

13. Khavas Z, Mohammadi A, Hosseini SM, Fakhari J. Evaluation of Microbial Contamination of Sohan Produced in Qom, Iran, with Reference to National Standards. Arch Hyg Sci. 2019; 8(3): 172-7.

14. Mohammadi A, Hashemi M, Hosseini SM, Hosseini M. Antimicrobial Activity of Essential Oils of Cinnamomum zeylanicum, Mentha piperita, Zataria multiflora Boiss and Thymus vulgaris Against Pathogenic Bacteria. Med Lab J. 2016; 10(2): 32-40. DOI: 10.18869/acadpub.mlj.10.2.32.

15. ISIRI (Institute of Standards and Industrial Research of Iran). Milk and milk products - Determination of nitrogen content -Part 1:Kjeldahl principle and crude protein calculation. 2016;No: 9188-1(ICS: 67.100.10).

16. ISIRI (Institute of Standards and Industrial Research of Iran). Determination of fat content of cheese and melted cheese. No: 760.
17. ISIRI (Institute of Standards and Industrial Research of Iran). Determination of the ash content of processed cheese. No: 1755.

18. ISIRI (Institute of Standards and Industrial Research of Iran). Cheese and processed cheese productsDetermination of totall phosphorus contentMolecular absorption spectrometric method. 2013;No: 1808(ICS: 67.100.30).

19. Beig Mohammadi M, Bolandi M, Ghodusi HB. Production and physicochemical, rheological, sensory analysis of "Lour" cheese. Food Sci Technol. 2015; 12(49): 41-9.

20. Tajizadegan H, Doosti; A, Nasr D, Narges S. Health Quality Assessment and Microbial Contamination (Salmonella, Kelly Form, Escherichia Kelly and Staphylococcus aureus) in Kashk and Qara Qorut Traditional Chaharmahal and Bakhtiari Province. In: 15th Iranian Veterinary Congress, Tehran, Iranian Veterinary Society, [Internet]. 1387. Available from: https://www.civilica.com/Paper-THVC15-

THVC15 703.html

21. Frazier WC, Westhoff DC. Food Microbiology. $18^{\text {th }}$ ed. McGrawHill. India; 2003.

\section{How to Cite:}

This paper should be cited as: Chizari M, Hosseini SM, Mohammadi A, Fakhari J, Mashhadi Mohammadzadeh-Vazifeh M. [Evaluation of Microbial Contamination of Dried Black Curd (Gharahghorut) Produced in Iran]. mljgoums. 2020; 14(6): 48-54. DOI: 0.29252/mlj.14.6.48. 